Nat. Hazards Earth Syst. Sci., 18, 1121-1132, 2018

https://doi.org/10.5194/nhess-18-1121-2018

(C) Author(s) 2018. This work is distributed under

the Creative Commons Attribution 4.0 License.

\title{
Potential future exposure of European land transport infrastructure to rainfall-induced landslides throughout the 21 st century
}

\author{
Matthias Schlögl ${ }^{1,2}$ and Christoph Matulla ${ }^{3}$ \\ ${ }^{1}$ Transportation Infrastructure Technologies, Austrian Institute of Technology (AIT), Vienna, Austria \\ ${ }^{2}$ Institute of Applied Statistics and Computing, University of Natural Resources and Life Sciences (BOKU), Vienna, Austria \\ ${ }^{3}$ Department for Climate Research, Zentralanstalt für Meteorologie und Geodynamik (ZAMG), Vienna, Austria
}

Correspondence: Matthias Schlögl (matthias.schloegl@ait.ac.at) and Christoph Matulla (christoph.matulla@zamg.ac.at)

Received: 31 October 2017 - Discussion started: 2 November 2017

Revised: 16 February 2018 - Accepted: 2 March 2018 - Published: 11 April 2018

\begin{abstract}
In the face of climate change, the assessment of land transport infrastructure exposure towards adverse climate events is of major importance for Europe's economic prosperity and social wellbeing. In this study, a climate index estimating rainfall patterns which trigger landslides in central Europe is analysed until the end of this century and compared to present-day conditions. The analysis of the potential future development of landslide risk is based on an ensemble of dynamically downscaled climate projections which are driven by the SRES A1B socio-economic scenario. Resulting regional-scale climate change projections across central Europe are concatenated with Europe's road and railway network. Results indicate overall increases of landslide occurrence. While flat terrain at low altitudes exhibits an increase of about 1 more potentially landslide-inducing rainfall period per year until the end of this century, higher elevated regions are more affected and show increases of up to 14 additional periods. This general spatial distribution emerges in the near future (2021-2050) but becomes more pronounced in the remote future (2071-2100). Since largest increases are to be found in Alsace, potential impacts of an increasing amount of landslides are discussed using the example of a case study covering the Black Forest mountain range in Baden-Württemberg by further enriching the climate information with additional geodata. The findings derived are suitable to support political decision makers and European authorities in transport, freight and logistics by offering detailed information on which parts of Europe's ground transport network are at particularly high risk concerning landslide activity.
\end{abstract}

\section{Introduction}

Given the outstanding importance of land transport modes for Europe's social and economic prosperity, the free and uninterrupted movement of persons and freight is critical. For instance, the accessibility of healthcare facilities, the supply of daily goods and a broad range of community services rely on the continuous availability of road and railway connections.

Extensive soil sealing across Europe (Nestroy, 2006), climate change (European Environment Agency, 2014; Loveridge et al., 2010) and extreme weather impacts (Schlögl and Laaha, 2017) challenge the resilience of transport systems, thus growing into a matter of major concern, not only because of physical damage to assets (Kellermann et al., 2015), but also due to potential overall societal losses caused by network failures and interruptions, which often far exceed infrastructure damage (Postance et al., 2017; Pfurtscheller and Vetter, 2015; Bíl et al., 2015; Pfurtscheller, 2014; Pfurtscheller and Thieken, 2013; Meyer et al., 2013). Thus, the assessment of land transport infrastructure exposure towards adverse climate events and related natural hazards is of great importance for Europe's economy, for its intermodal transport, its freight and logistics networks and for settlements in hazard-prone regions (Koetse and Rietveld, 2009; Doll et al., 2014). Therefore, information on current climate and its variability and on potential future climate changes is of prime importance for proactive planning and the development of adaptation strategies concerning ground transport's operation, maintenance, reinforcement and construction as well as for civil protection. 
Climate change and alterations in extreme weather events - which affect ecosystems and man-made infrastructure have been investigated for decades (e.g. IPCC, 1990, 1995, 2001, 2007, 2012, 2014b). Among various threatening hazards, landslides stand out as particularly destructive to the function and structural integrity of ground transport systems, since they cause long downtime and require exceedingly expensive repairs. Even though observed changes in extreme events in terms of frequency, intensity and duration may not be directly associated with global warming, trends concerning landslide occurrence are visible (Gariano and Guzzetti, 2016; McBean, 2011; Crozier, 2010). Therefore, information about expected future changes in landslide occurrence and its impacts on land transport infrastructure may provide a basis for the implementation of adequate adaptation measures.

Ever since the impact of humankind on the climate system has been proven (e.g. IPCC, 2000) it has become increasingly important to derive estimates of future climate states. Global climate models (GCMs) are state-of-the-art tools used to investigate future climate development, mimicking globalscale consequences for the climate system. GCM results are valid on global and continental scales and have to be downscaled (e.g. von Storch et al., 1993) to regional scales for the assessment of future hazard occurrence. This approach has been shown to yield valuable results for the evaluation of rainfall-induced landslides at regional scales (Gariano et al., 2017a; Matulla et al., 2017).

Studies about the effects of climate change on landslide activity have gained centre stage in recent years. Crozier (2010) was one of the first to systematically examine the underlying mechanisms linking climate change impacts and slope stability. It was noted in this work that while there is a strong theoretical basis for increased landslide activity as a result of a changing climate, a certain extent of uncertainty remains due to inherent incompleteness and inhomogeneities of historic data on climate and landslide records, the nature of scenariobased projections and the lack of downscaled data at an appropriate spatial resolution. However, changes in annual and seasonal precipitation patterns (in terms of both precipitation totals and intensity) have been found to be key determinants affecting landslides (Gariano and Guzzetti, 2016; Sidle and Ochiai, 2013).

Since the difficulties of establishing a universal relationship between climate change and landslides across Europe was noted by Dikau and Schrott (1999), citing the complexity of the problem as the main obstacle, several authors have attempted to establish such relationships for different parts of the continent (e.g. Gariano et al., 2017b; Gariano and Guzzetti, 2016; Jaedicke et al., 2014; Promper et al., 2014; Van Den Eeckhaut et al., 2012; Crozier, 2010).

The derivation of future climate change-induced hazards is essentially based on two key components: (i) sets ("ensembles") of GCM runs, which are driven by potential future pathways of humankind and cascaded down to regional scales via downscaling techniques (e.g. von Storch et al.,
1993; Matulla et al., 2003) and (ii) relationships (climate indices, CIs) between regional-scale climate phenomena (e.g. long-term rain exceeding certain thresholds) and damage events. Ensembles of climate change projections depicting corridors of future climate evolutions and CIs can be arranged in so-called cause-effect tensors, which have been successfully applied to assess the potential of future damaging events on European transport infrastructure (Matulla et al., 2017).

Rainfall periods exceeding certain thresholds have been found to serve as a proper proxy for landslide occurrence and been applied in central Europe (Peruccacci et al., 2017; Matulla et al., 2017; Gariano et al., 2017a; Brunetti et al., 2010; Guzzetti et al., 2008, 2007; Dixon and Brook, 2007). Based on these findings, we employ a CI that inherits intensity and totals of severe rainfall events, which have been shown to act as a primary trigger of rapid-moving landslides in central Europe (Gariano and Guzzetti, 2016).

It must be noted that there are no unambiguous criteria that could be used for a geographically distinct delimitation of the central European region. In this study, we adjust the most widely accepted definition of central Europe - as used, for example, in the World Factbook (CIA, 2017) - according to the given data availability. Thus, the following countries are considered (at least partially) in the present study: Austria, Belgium, Czech Republic, France, Germany, Liechtenstein, Luxembourg, the Netherlands and Switzerland.

In order to illustrate the implications of these meteorological impacts in a more practical context, results of the CI exposure mapping are enriched with additional environmental information using the example of a selected risk-prone area located around the tripoint of France, Germany and Switzerland in the Upper Rhine Valley. Hence, we amplify the scope of the discussion by embedding mesoscale CI data (obtained via downscaling of GCMs) into a specific regional context featuring additional information about environmental properties such as data on geomorphology, soil or land cover.

This study is devoted to the assessment of climate-changedriven landslide hazards to European transport infrastructure (rails and roads) in the near (2021-2050) and the remote (2071-2100) future. Results are based on the A1B socioeconomic scenario (IPCC, 2000) and shall provide European transport authorities with auxiliary information for setting up cost effective and spatially targeted protection measures in order to safeguard Europe's transport system in the future.

\section{Data}

\subsection{Climate}

Since the goal of this study is to investigate potential changes in landslide occurrence jeopardising Europe's transport infrastructure, climate data used cover two future periods rela- 
tive to past conditions: the near future (2021-2050) and the remote future (2071-2100).

The assessment of future climate threats jeopardising central European transport assets relies on ensembles of daily based, regional-scale climate change projections. Such ensembles of climate change projections - driven by potential pathways of humankind - can be generally derived via two techniques: dynamic and statistical-empirical downscaling (Matulla et al., 2002; von Storch et al., 1993). Here we make use of an ensemble consisting of 17 climate model runs that has been applied to create dynamically downscaled and bias-corrected (and hence physically consistent) future projections of climate states for climate change impact investigation (Imbery et al., 2013). The projections are driven by the A1B SRES socio-economic scenario, which describes a future world characterised by dynamic economic development, decreasing social and income inequalities, a rapid dissemination of new and efficient technologies and a balanced use of energy sources (IPCC, 2000).

\subsection{Infrastructure}

The road infrastructure network figure is based on a data extract of OpenStreetMap (OSM) obtained in June 2017. The high-level road network used in this study is derived from the OSM data set by applying a filter selecting only the following motorway tags: motorway, motorway_link, trunk, trunk_link, primary and primary_link. The network selected in this way contains motorways and major roads (OSM, 2017). The railway network is represented by the Natural Earth Railroads vector data set, version 3.0.0 (Natural Earth, 2017). In order to obtain results at an adequate resolution, all connections exceeding $500 \mathrm{~m}$ have been split into multiple segments every $500 \mathrm{~m}$.

\subsection{Topography}

The digital elevation model EU-DEM v1.1 is used in this study to analyse topographic properties. This DEM, which is a hybrid product based on SRTM (Shuttle Radar Topography Mission) and ASTER (Advanced Spaceborne Thermal Emission and Reflection Radiometer) DEM data, fused by a weighted average approach, is provided by the Copernicus programme (Copernicus, 2017). The slope and terrain ruggedness index (TRI) are derived from this DEM with gdaldem using Horn's formula (Horn, 1981).

\subsection{Additional geodata}

In addition, data sets on geological and soil properties, and rainfall erosivity and land cover data have been used to augment the discussion of the implications imposed by the derived CI. CORINE Land Cover data are provided by the Copernicus programme (Copernicus, 2017). The geology data set (IGME 5000) is provided by the Federal Institute for Geosciences and Natural Resources (Asch, 2005), while soil and rainfall erosivity data are accessible through the European Soil Data Centre (Panagos et al., 2012). Please note that all of these data sources are freely accessible. The respective sources for all data sets are referenced in the data availability section at the end of the paper.

\section{Methods}

The gridded data sets of daily precipitation totals derived from the 17-member ensemble of climate model runs forced by the A1B socio-economic scenario are available on a $5 \mathrm{~km}$ grid across large parts of central Europe (cf. Fig. 1). These raster data sets were used to calculate the landslide CI for central Europe at the same spatial resolution. The CI for potentially landslide-triggering events was established by using a proxy indicating precipitation periods extending over at least 3 days, while generating overall totals of more than $37.3 \mathrm{~mm}$, and exhibiting at least 1 day with a total exceeding $25.6 \mathrm{~mm}$. This threshold for landslide activity was proposed by Guzzetti et al. (2008) and was recently used to establish a CI for landslide occurrence based on threshold exceedance in Matulla et al. (2017). Changes in hazard occurrence (predefined via this $\mathrm{CI}$ ) over time can be analysed by comparison of past and potential future probability density functions.

In order to obtain information on the exposure of road and railway assets in central Europe at the network level, CI values from gridded data sets described above were mapped to the underlying road and rail segments. This was achieved by extracting and interpolating corresponding values from the raster grid towards the road and railway network figures.

For the sake of putting the landslide exposure maps obtained into a more representative context concerning the interpretation and discussion of practical implications, maps depicting slope angles, terrain ruggedness, geomorphologic properties and rainfall erosivity and land cover were created for a particularly risk-prone area, henceforth referred to as the target region. The obtained landslide exposure, which is based on the selected CI, is then analysed and discussed against the background of these additional environmental features that are widely used in landslide studies (e.g. Jaedicke et al., 2014; Papathoma-Köhle and Glade, 2013; Van Den Eeckhaut et al., 2012).

As far as topography is concerned, the slope angle and the TRI are considered. Slope angles are known to be a key parameter in estimating susceptibility to developing earth flows (Donnarumma et al., 2013). The TRI is defined as the mean difference between a central pixel and its surrounding cells (Wilson et al., 2007) and can be used to quantify landscape heterogeneities, which could exert influence on the localisation of the triggering area of shallow landslides (Persichillo et al., 2016). Both properties are derived from the DEM using Horn's formula (Horn, 1981).

Information concerning the nature and the properties of the ground, which are known to be important aspects affecting 
landslide susceptibility, rock and soil type have been mapped for the target region. Lithological types are obtained from the International Geological Map of Europe and Adjacent Areas (Asch, 2005), and the dominant Soil Typological Unit is mapped according to the World Reference Base for Soil Resources as available in the European Soil Database (Panagos et al., 2012; Panagos, 2006).

The topographic, geological and soil properties data sets and data on rainfall erosivity and land cover have been used solely to augment the discussion of the implications imposed by the derived $\mathrm{CI}$.

\section{Results and discussion}

In terms of the time horizon under consideration, results of this study refer to two different time periods throughout the 21 st century. The first period (near future) covers the years 2021 to 2050, while the second period (remote future) ranges from 2071 to 2100 . In this context it must be noted that projected precipitation values obtained from the ensemble of 17 climate model runs are relative to current climate conditions. This implies that all results have to be interpreted as variations that are averaged over the whole future period with respect to present-day conditions as a baseline reference.

\subsection{Central Europe}

Results are visualised as exposure maps for both the highlevel road network (Fig. 1) and the railway network (Fig. 2) in central Europe. In order to provide information about future probability density functions of the selected CI (and not only about the best estimate), their quartiles (i.e. 25th percentile and median and 75th percentile) are reported for each of the two time periods under consideration, resulting in six different facets.

Generally speaking, results show that the most risk-prone areas are located in regions that are characterised by structured topography, for example, in uplands or Alpine forelands. Concerning near-future changes, at least a slight increase of rainfall-induced landslides has to be expected over the entire region. As expected, only the near future 25th percentile does not show any changes in potential landslide occurrence in certain lowland areas, which are mainly located in north-eastern and central Germany. This is consistent with the physics of maritime-influenced regions since large water bodies tend to dampen rapid changes in surrounding areas. In contrast, there are several regions that are expected to face up to seven additional landslide-inducing periods, namely the Vosges, the Black Forest (Schwarzwald), the Swabian Jura (Schwäbische Alb), the Bergisches Land, the Jura Mountains, the foothills of the Northern Limestone Alps, the Alpine foreland in Austria and Bavaria, and the Bohemian Forest $(\breve{S} u$ mava or Böhmerwald).
Our findings show that changes in occurrence frequencies of landslide-triggering extreme climate events slightly increase over time, as is clearly visible when comparing the second rows of Figs. 1 and 2 to the first rows. Basically, the same patterns apply, but the magnitude of the changes is increased in the remote-future period. This is largely consistent with findings from the IPCC's Fifth Assessment Report (IPCC, 2014a). It must be noted, though, that the overall occurrence of landslide-inducing rainfall events appears to increase only slightly in pace throughout the 21 st century. Nevertheless, the aforementioned areas along the north side of the Alps are likely to experience substantially increased landslide activity in the remote future compared to current climate conditions, pointing to an acceleration of landslide occurrence and showing a possible increase of up to 14 additional landslide-triggering rainfall events (see Table 1).

As uncertainty about future projections increases, the spread between the first and third quartile of the projections grows as well, showing variations of up to seven events for the remote-future period. This coincides with our expectations, since coherence amongst projections decreases towards the end of this century. In addition, the underlying patterns of the geographical distributions of the results are similar, indicating overall robust results.

With respect to infrastructure exposure towards potential landslide susceptibility the following regions can be determined:

1. regions with a substantial increase in rainfall-induced landslide activity are the Jura Mountains, the Vosges, the Black Forest, the Swabian Jura, the Bavarian Prealps, the foothills of the Austrian Alps and the Bohemian Forest;

2. regions with less pronounced variations in the CI under consideration that are nonetheless clearly distinct from their surroundings are the Bergisches Land, the Harz, the Fichtel Mountains, Vogtland and the Ore Mountains;

3. the rest of central Europe, where changes in frequencies of rainfall-induced landslides are expected to be minor.

As far as the backbones of the European road and railway infrastructure (Trans-European Transport Networks, TEN-T) are concerned, most TEN-T core-network corridors are likely to be affected by increased landslide activity. In particular, the Rhine-Danube corridor (Strasbourg-Karlsruhe, Munich-Rosenheim-SalzburgLinz, Regensburg-Passau-Linz), the ScandinavianMediterranean (Munich-Rosenheim-Kufstein), the Rhine-Alpine and North Sea-Mediterranean corridors (Karlsruhe-Strasbourg-Basel, onwards to Belfort, Bern, Lucerne and Zurich) and the North Sea-Baltic corridor (in the area of Wuppertal) have been identified as areas potentially facing increased exposure to landslide-inducing rainfall events. 

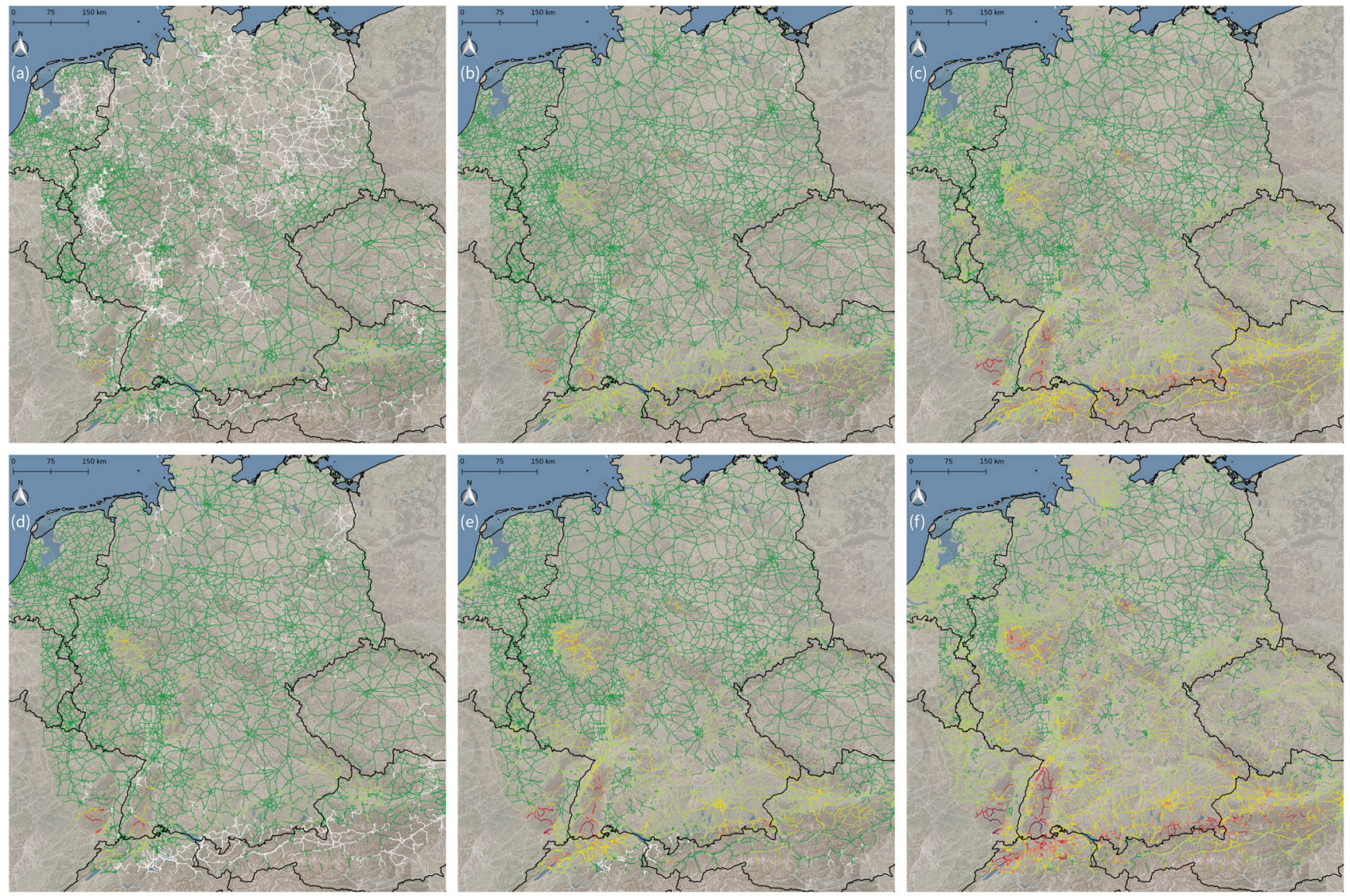

$$
\begin{gathered}
-\leq 0-(0-1)-[1-2)-[2-3)-[3-4)-[4-5)-[5-7)-[7-9)-[9-11)-[11-13)-[13-15] \\
{\left[\text { Periods year }{ }^{-1}\right]}
\end{gathered}
$$

Figure 1. Projected changes in the annual number of periods exceeding rainfall thresholds for the possible occurrence of landslides (precipitation totals $>25.6 \mathrm{~mm} \mathrm{~d}^{-1}$ and $>37.3 \mathrm{~mm}(3 \mathrm{~d})^{-1}$ ) concerning the high-level road network in central Europe. The first row (a-c) shows near-future projection results and the second row (d-f) displays projection results for the remote future. The three columns represent the quartiles in increasing order, with (a) and (d) displaying the lower quartile, (b) and (e) displaying the median and (c) and (f) displaying the upper quartile

Table 1. Summary statistics for the six different facets displayed in Figs. 1 and 2 based on all raster cells covering road or rail infrastructure links. Results refer to the relative changes compared to present-day conditions, values indicate the magnitude of changes in the number of periods exceeding the CI thresholds.

\begin{tabular}{lrrrrr}
\hline Period & Minimum & First quartile & Median & Third quartile & Maximum \\
\hline Near future (first quartile) & -1.53 & 0.00 & 0.13 & 0.33 & 4.97 \\
Near future (median) & -0.07 & 0.30 & 0.50 & 0.83 & 5.97 \\
Near future (third quartile) & 0.13 & 0.63 & 0.90 & 1.40 & 7.37 \\
\hline Remote future (first quartile) & -6.08 & 0.17 & 0.33 & 0.57 & 6.72 \\
Remote future (median) & -1.80 & 0.53 & 0.73 & 1.13 & 10.54 \\
Remote future (third quartile) & -0.53 & 0.90 & 1.20 & 1.83 & 13.97 \\
\hline
\end{tabular}

\subsection{Target area}

Meteorological impacts on geomorphological events driving landscape change processes over short timescales have been found to have serious consequences, particularly in climatesensitive regions such as the European Alps Keiler et al. (2010). Yet it must be noted that while this analysis refers to 

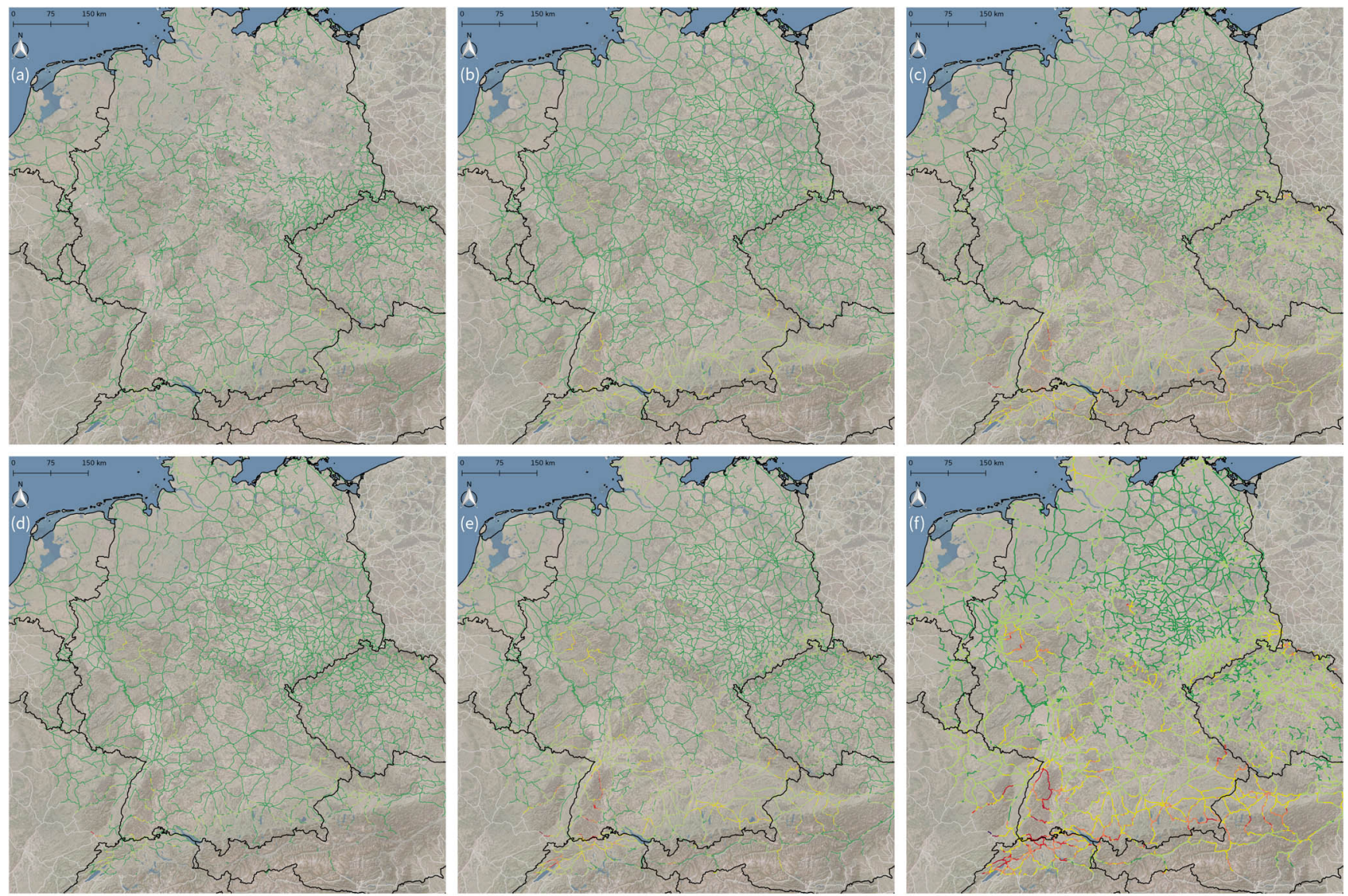

Legend

$=\leq 0-(0-1)-[1-2)-[2-3)-[3-4)-[4-5)-[5-7)-[7-9)-[9-11)-[11-13)-[13-15]$

[Periods year ${ }^{-1}$ ]

Figure 2. Projected changes in the annual number of periods exceeding rainfall thresholds for the possible occurrence of landslides (precipitation totals $>25.6 \mathrm{~mm} \mathrm{~d}^{-1}$ and $>37.3 \mathrm{~mm}(3 \mathrm{~d})^{-1}$ ) concerning the railway network in central Europe. The first row shows near-future projection results and the second row displays projection results for the remote future. The three columns represent the quartiles in increasing order, with (a) and (d) displaying the lower quartile, (b) and (e) displaying the median, and (c) and (f) displaying the upper quartile

potentially hazardous rainfall events that may trigger landslides, other environmental information has not been taken into account so far. Therefore, the consideration of reduced static information commonly used for landslide susceptibility evaluations (Günther et al., 2014, 2013; Hervás et al., 2007) is illustrated and discussed in the example of a particularly risk-prone area.

The selected region is centred around the lowlands of Alsace and the Black Forest mountain range, covering parts of France, Germany, Switzerland, Luxembourg and Austria (Fig. 3). This area has been selected for two reasons. First, it is a region showing one of the largest increases in the selected CI. Second, the consequences of interruptions are quite severe in this area, as the recent mass movements in the Rhine Valley between Baden-Baden and Rastatt have shown (Ackeret, 2017).
As far as topography is concerned, results show that the target region is not only prone to an increased amount of rainfall that induces landslides, it is also susceptible to mass wasting due to its topographic properties (Fig. 4). Road and rail infrastructure in this area are frequently located in rugged terrain, in valleys, on hillsides or at the foothills of mountains. This is particularly the case for the Rhine-Alpine corenetwork corridor, parts of which are located along the steep western slopes of the Black Forest.

Regarding nature and the properties of the ground (Fig. 5), sedimentary rock types (sandstone, mudstone and limestone) are prevalent in the area. Igneous (granite and basalt) and metamorphic (gneiss and schists) rocks can be found in the Vosges and Schwarzwald mountain ranges and the Kaiserstuhl volcano. Generally speaking, the higher the rock strength, the greater the rainfall required to trigger landslides. It has been found that the rainfall threshold for sandstone 

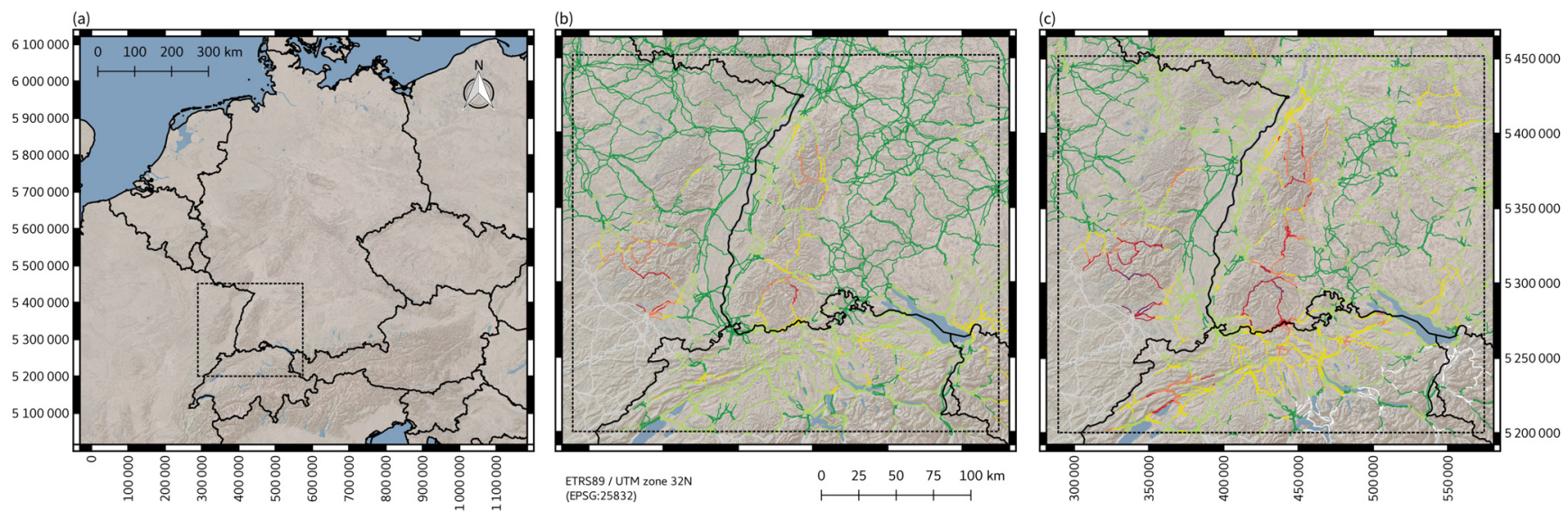

Figure 3. Overview of the target region: (a) location of the region in central Europe and median of the increase in landslide-triggering climate events for (b) the near future and (c) the remote future.

and marl is lower than the threshold for limestone, limited marl and chert, which in turn is lower than the threshold for metamorphic rocks (Peruccacci et al., 2017). Cambisols are the prevailing soil type across major parts of the study area. The Upper Rhine Plane shows a predominance of Fluvisols. While the Vosges as well as the Palatinate Forest are characterised by Podzols, the Swabian Jura is mainly covered by Leptosols. The south-eastern parts, towards the alpine foothills, contain highly structured soil types with clay-enriched subsoil and soils influenced by water; Leptosols and Podzols are common in these areas. Landslide susceptibility studies in the Swabian Alb have found that slopes with angles from 11 to $26^{\circ}$, consisting of colluvial layers, Rendzic Leptosol and clayey soils superimposed on marl debris, are indicators for slope instability in this area (Terhorst, 2007; Neuhäuser and Terhorst, 2007).

Our analysis is completed by mapping rainfall erosivity in terms of the $R$ factor and land cover for the target region (Fig. 6). $R$ factors between 700 and $1500 \mathrm{MJ} \mathrm{mm} \mathrm{ha}^{-1} \mathrm{~h}^{-1} \mathrm{yr}^{-1}$ can be observed across extensive parts of the target region. While rainfall erosivity is comparably low in the lowlands of Alsace, it rapidly increases in the adjacent uplands, particularly towards the south. As pointed out by Panagos et al. (2015), a combination of large rainfall amounts and high erosivity densities - a condition that applies to major parts of the target region - is a precondition for landslides.

Concerning land cover, the target region is characterised by a multitude of small-scale areas with different land cover classes, typical for heterogeneous areas in complex terrain in central Europe. Lowland areas are typically characterised by arable land (e.g. vineyards in the Upper Rhine Plain), while forests prevail with increasing altitude. It is broadly recognised in landslide research literature that forested areas favour terrain stability, while agricultural areas and abandoned cultivated lands that gradually recovered through natu- ral vegetation are particularly susceptible to instability (Persichillo et al., 2017; Peruccacci et al., 2017; Petitta et al., 2015; Reichenbach et al., 2014; Beguerí, 2006).

Consequences of traffic interruptions in this area are severe, as the closure of the Rhine Valley railway from $13 \mathrm{Au}-$ gust to 2 October 2017 showed. This interruption of this important north-south transport corridor, caused by mass movements at the construction site of the Rastatt Tunnel, led to considerable delays and increased costs, particularly for freight transport. This traffic artery, which connects Italian ports with the ports of Rotterdam, Hamburg, Bremerhaven and Basel to the container port Duisburg is usually used by up to 350 trains per day. The interruption of the track at Rastatt resulted in a massive congestion of freight trains all along the route due to the lack of alternative transport lines as well as the lack of engines and railroad engineers at alternative routes (FAZ, 2017; Ackeret, 2017; Gafner and Sommer, 2017). In addition to the direct economic damage, indirect and intangible costs such as noise disturbance and air pollution caused by an increased amount of cargo trains and heavy goods vehicles using alternative routes and the increased travel time for commuters, travellers and vacationers should be considered (Postance et al., 2017).

\section{Outlook}

In this paper we highlight potential future changes of rainfallrelated climate phenomena linked to landslide activities. We derive and present general patterns regarding the future rainfall-induced landslide exposure of road and railway networks in central Europe and delineate the enrichment of such climate-change-related exposure information with additional relevant geodata in selected risk-prone areas.

Our findings indicate overall increases of landslide activity in the central European region. However, while results suggest that flat orography at low altitudes will face only mi- 


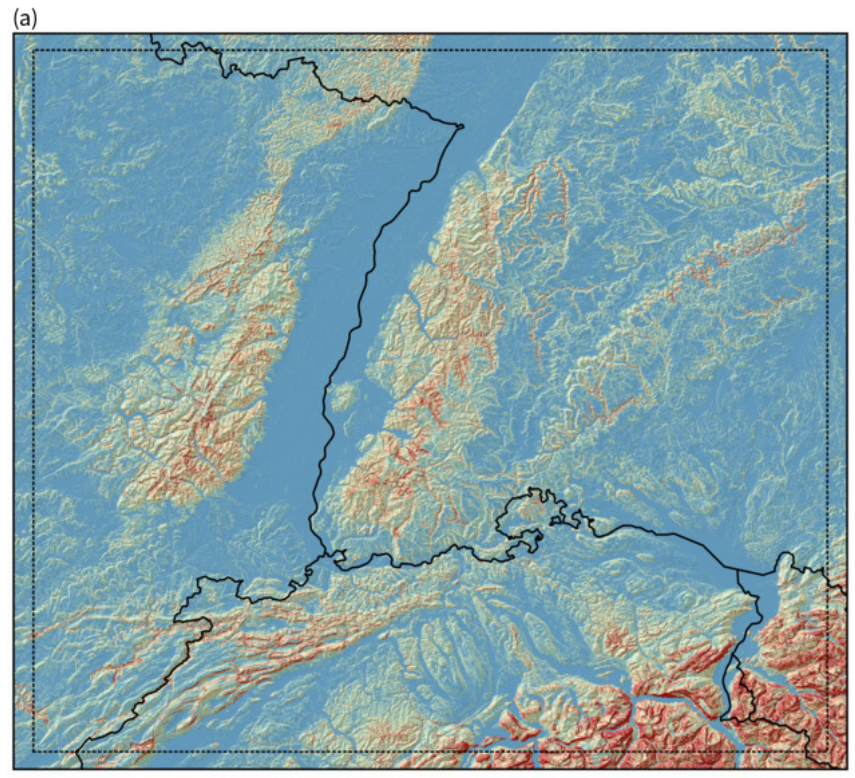

Slope ["]

$\square \leq 5 \square(5-10] \square(10-15] \square(15-20] \square(20-25] \square(25-30] \square>30$

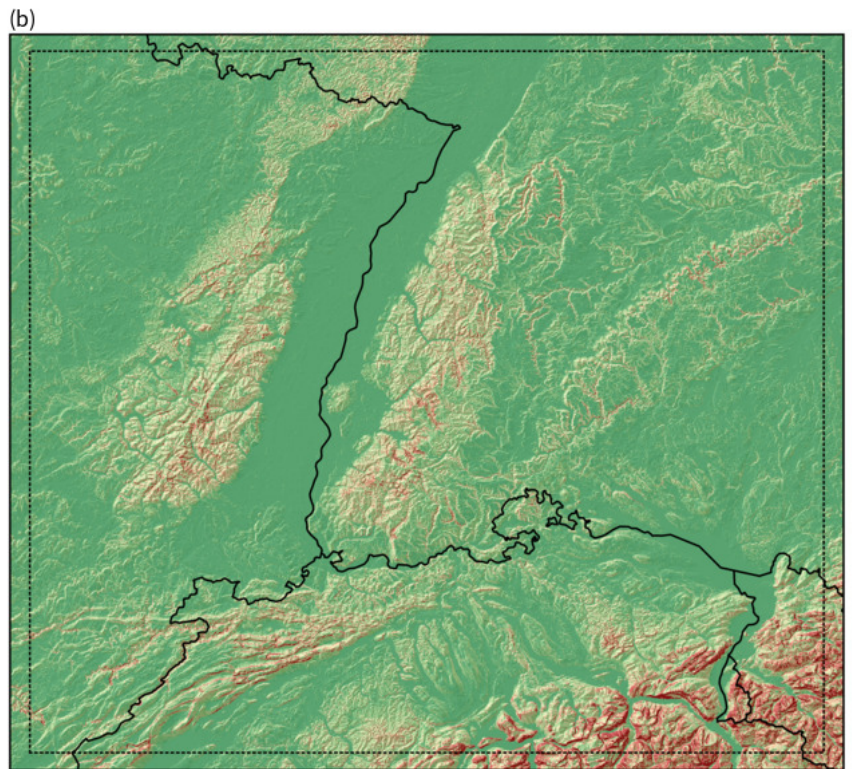

Terrain ruggedness index []

$\square \leq 2 \square(2-4] \square(4-6] \square(6-8] \square(8-10] \square(10-12] \square>12$

岁 $\begin{array}{lllll}0 & 25 & 50 & 75 & 100 \mathrm{~km}\end{array}$

Figure 4. (a) Slope and (b) terrain ruggedness index in the target region.
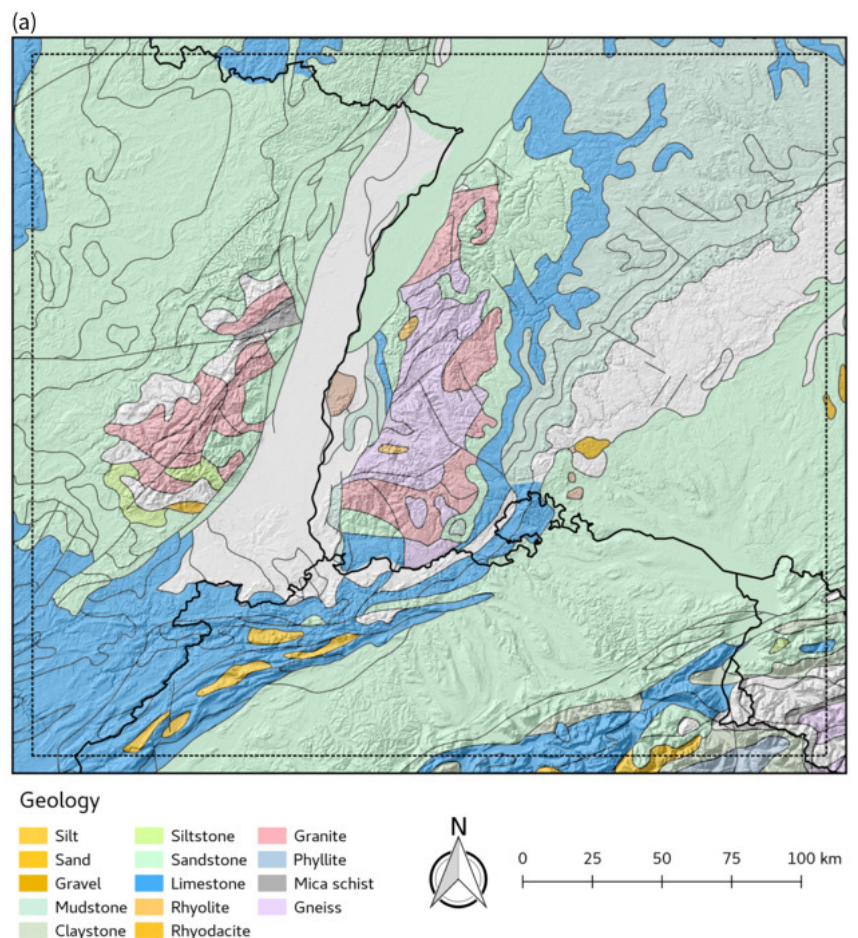

(b)

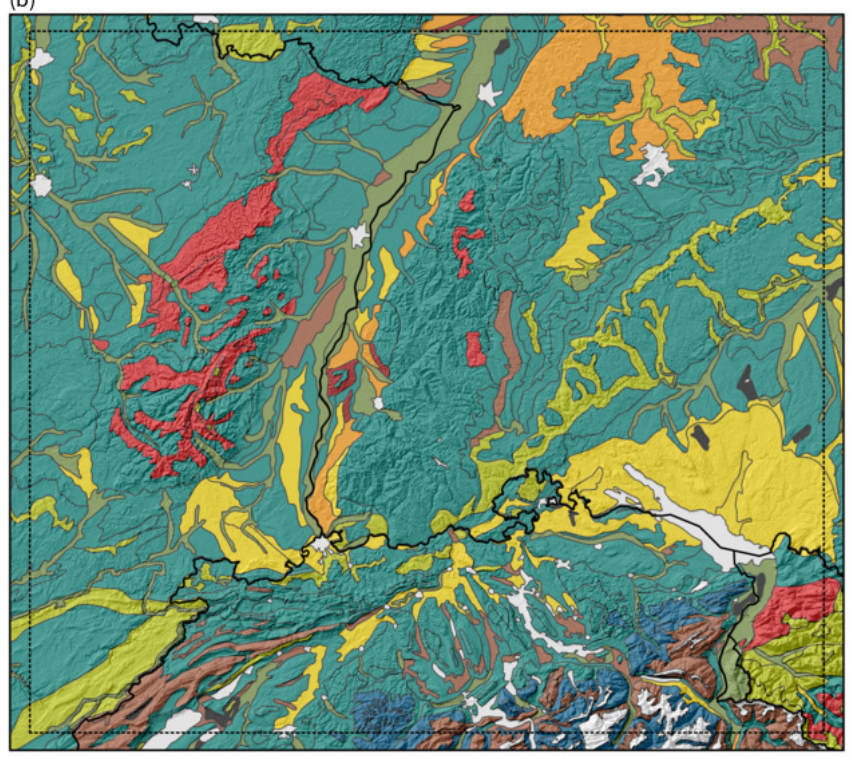

Dominant soil typology

$\square$ Retisols $\square$ Fluvisols $\square$ Luvisols $\square$ Planosols $\square$ Gleysols

Figure 5. (a) Geology, including geological faults and (b) soil in the target region. 

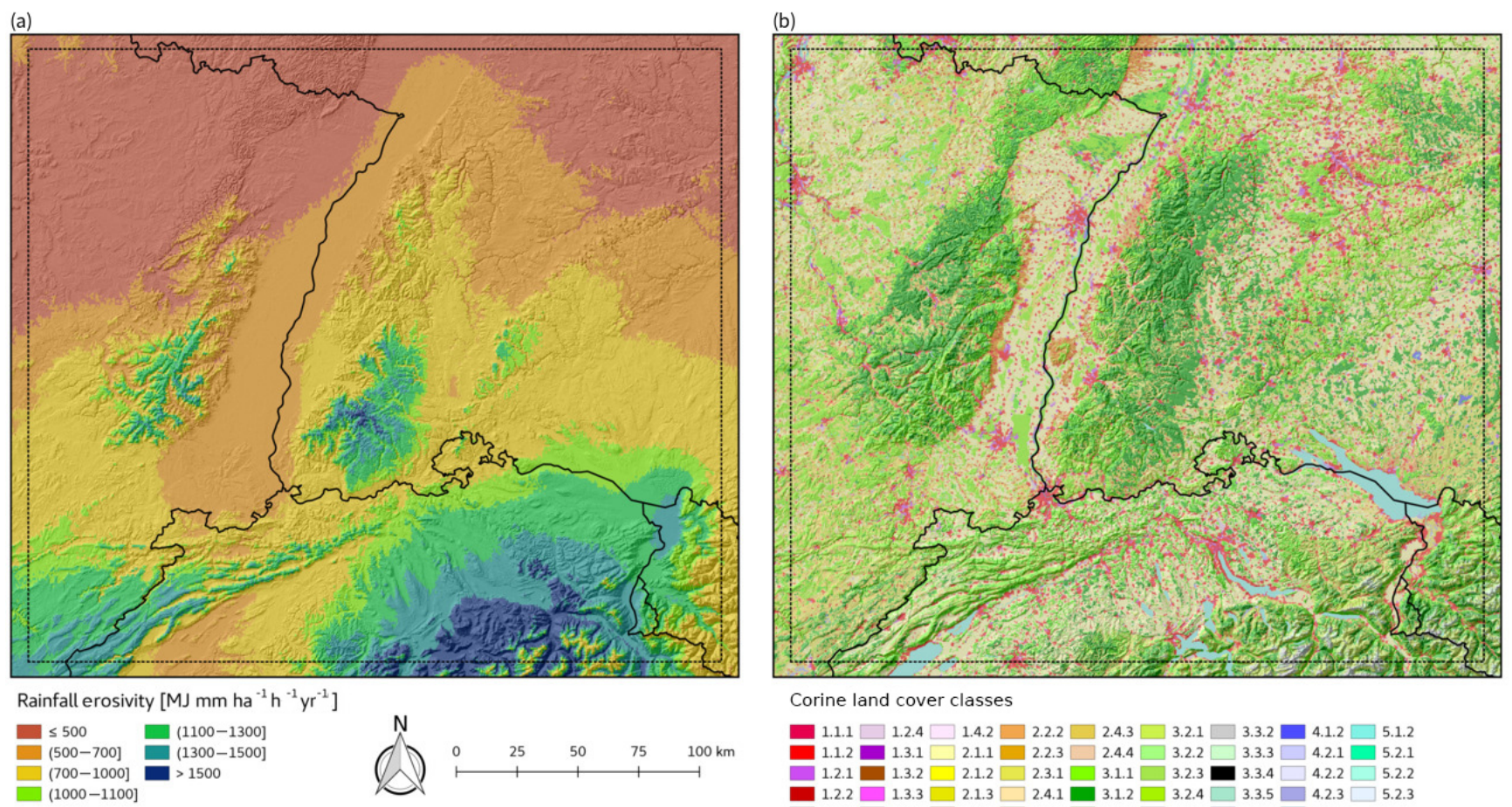

Corine land cover classes

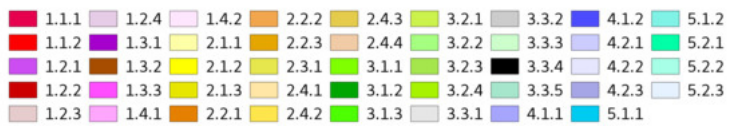

Figure 6. (a) Erosivity and (b) land cover in the target region.

nor increases of potentially landslide-inducing rainfall periods per year until the end of this century, this effect is far more severe in complex terrain, where increases of up to 14 additional periods are to be expected. This general spatial distribution emerges in the near future (2021-2050), but becomes more pronounced in the remote future (2071-2100).

Most notably, mountainous regions and rolling landscapes - which exhibit the strongest increases in landslide-inducing rainfall periods - are particularly susceptible to landslides due to their topographic properties. Against the background that ground transport infrastructure networks in higher elevated regions usually do not feature redundant structural elements at comparable economic efficiency, an increased exposure towards landslide-inducing rainfall events is likely to have potentially severe impacts on alpine communities if appropriate adaptation measures and precautions are not taken.

In the example of a particularly risk-prone area covering parts of France, Germany, Switzerland and Austria, the added value attained by including additional maps derived from various geodata sources is demonstrated. Considering these regional conditions is of critical importance for putting exposure to climate events in context.

Future work should focus on the implications of exposure analyses for infrastructure users. This includes the extension of the investigated region to the whole of Europe as well as the consideration of additional climate indices describing further climate-driven impacts. In order to provide decision support for stakeholders, future efforts should include network analysis and traffic modelling, as this will provide deeper insights into regional mobility behaviour and criticality assessment of important links in the network. Eventually, investigating socio-economic impacts and vulnerability and risk management is of prime importance for the establishment of effective adaption measures in the context of climate change.

Data availability. Strong focus was put on using open access data wherever possible. Road data are accessible via the OSM API under http://api.openstreetmap.org/ and railroad data from Natural Earth are available at https:/github. com/nvkelso/natural-earth-vector/tree/master/10m_cultural or via the front end at http://www.naturalearthdata.com/downloads/ $10 \mathrm{~m}$-cultural-vectors/railroads/. CORINE Land Cover data and the EU-DEM are provided by the Copernicus land monitoring service and can be accessed at http://land.copernicus.eu/. The geology data set (IGME 5000) is provided by the Federal Institute for Geosciences and Natural Resources at https://produktcenter.bgr.de/. Soil data and rainfall erosivity are accessible through the European Soil Data Centre (ESDAC) at http://esdac.jrc.ec.europa.eu/ resource-type/datasets.

\footnotetext{
The Supplement related to this article is available online at https://doi.org/10.5194/nhess-18-1121-2018supplement.
} 
Competing interests. The authors declare that they have no conflict of interest.

Special issue statement. This article is part of the special issue "Landslide-road network interactions". It is not associated with a conference.

Acknowledgements. The authors would like to thank Melitta Dragaschnig (AIT) for providing assistance with OSM data extraction. We thank the two anonymous reviewers and the editor for providing insightful comments and suggestions on an earlier draft of the manuscript.

Edited by: Faith Taylor

Reviewed by: two anonymous referees

\section{References}

Ackeret, M.: Rheintalbahn-Sperrung: Desaster für den Güterverkehr, Neue Züricher Zeitung, 16 August 2017, https://www.nzz.ch/panorama/sperrung-der-eisenbahnlinie-beirastatt-desaster-fuer-den-gueterverkehr-und-fuer-die-neuedeutsche-rheintalstrecke-ld.1311011, 2017.

Asch, K.: IGME 5000:1:5 Million International Geological Map of Europe and Adjacent Areas, BGR (Hannover), https: //www.bgr.bund.de/EN/Themen/Sammlungen-Grundlagen/ GG_geol_Info/Karten/International/Europa/IGME5000/IGME_ Project/IGME_Projectinfo.html, last access: 21 August 2017, 2005.

Beguería, S.: Changes in land cover and shallow landslide activity: A case study in the Spanish Pyrenees, Geomorphology, 74, 196206, https://doi.org/10.1016/j.geomorph.2005.07.018, 2006.

Bíl, M., Vodák, R., Kubeček, J., Bílová, M., and Sedoník, J.: Evaluating road network damage caused by natural disasters in the Czech Republic between 1997 and 2010, Transport. Res. A-Pol., 80, 90-103, https://doi.org/10.1016/j.tra.2015.07.006, 2015.

Brunetti, M. T., Peruccacci, S., Rossi, M., Luciani, S., Valigi, D., and Guzzetti, F.: Rainfall thresholds for the possible occurrence of landslides in Italy, Nat. Hazards Earth Syst. Sci., 10, 447-458, https://doi.org/10.5194/nhess-10-447-2010, 2010.

CIA: The World Factbook, Central Intelligence Agency, https://www.cia.gov/library/publications/the-world-factbook/ fields/2144.html, 2017.

Copernicus: EU-DEM v1.1, http://land.copernicus.eu/ pan-european/satellite-derived-products/eu-dem/eu-dem-v1.1, last access: 21 August 2017, 2017.

Copernicus: CORINE Land Cover, https://land.copernicus.eu/ pan-european/corine-land-cover, last access: 29 March 2018.

Crozier, M.: Deciphering the effect of climate change on landslide activity: A review, Geomorphology, 124, 260-267, https://doi.org/10.1016/j.geomorph.2010.04.009, 2010.

Dikau, R. and Schrott, L.: The temporal stability and activity of landslides in Europe with respect to climatic change (TESLEC): main objectives and results, Geomorphology, 30, 112, https://doi.org/10.1016/S0169-555X(99)00040-9, 1999.
Dixon, N. and Brook, E.: Impact of predicted climate change on landslide reactivation: case study of Mam Tor, UK, Landslides, 4, 137-147, https://doi.org/10.1007/s10346-006-0071-y, 2007.

Doll, C., Trinks, C., Sedlacek, N., Pelikan, V., Comes, T., and Schultmann, F.: Adapting rail and road networks to weather extremes: case studies for southern Germany and Austria, Nat Hazards, 72, 63-85, https://doi.org/10.1007/s11069-013-0969-3, 2014.

Donnarumma, A., Revellino, P., Grelle, G., and Guadagno, F. M.: Slope Angle as Indicator Parameter of Landslide Susceptibility in a Geologically Complex Area, in: Landslide Science and Practice: Volume 1: Landslide Inventory and Susceptibility and Hazard Zoning, edited by: Margottini, C., Canuti, P., and Sassa, K., Springer, Berlin, Heidelberg, 425-433, https://doi.org/10.1007/978-3-642-31325-7_56, 2013.

ESDAC: Rainfall Erosivity in the EU and Switzerland (R-factor), https://esdac.jrc.ec.europa.eu/content/ rainfall-erosivity-european-union-and-switzerland, last access: 29 March 2018a.

ESDAC: European Soil Database v2.0 (vector and attribute data), https://esdac.jrc.ec.europa.eu/content/ european-soil-database-v20-vector-and-attribute-data, last access: 29 March 2018b.

European Environment Agency: Adaptation of transport to climate change in Europe, European Environment Agency, EEA Report No 8/2014, 2014.

FAZ: Gesperrte Rheintalbahn: Wieder Erdbewegungen an Bahnstrecke in Rastatt, Frankfurter Allgemeine Zeitung, $15 \mathrm{Au}-$ gust 2017, http://www.faz.net/aktuell/gesellschaft/ungluecke/ rheintalstrecke-sperrung-haelt-weiter-an-15152374.html, 2017.

Gafner, B. and Sommer, A.: Transport-Chaos wegen Deutschland, Basler Zeitung, 17 August 2017, https://bazonline.ch/schweiz/ transportchaos-wegen-deutschland/story/18399414, 2017.

Gariano, S. L. and Guzzetti, F.: Landslides in a ch anging climate, Earth-Sci. Rev., 162, 227-252, https://doi.org/10.1016/j.earscirev.2016.08.011, 2016.

Gariano, S. L., Rianna, G., Petrucci, O., and Guzzetti, F.: Assessing future changes in the occurrence of rainfall-induced landslides at a regional scale, Sci. Total Environ., 596, 417-426, https://doi.org/10.1016/j.scitotenv.2017.03.103, 2017a.

Gariano, S. L., Petrucci, O., Rianna, G., Santini, M., and Guzzetti, F.: Impacts of past and future land changes on landslides in southern Italy, Reg. Environ. Change, https://doi.org/10.1007/s10113017-1210-9, 2017b.

Günther, A., Reichenbach, P., Malet, J.-P., Van Den Eeckhaut, M., Hervás, J., Dashwood, C., and Guzzetti, F.: Tier-based approaches for landslide susceptibility assessment in Europe, Landslides, 10, 529-546, https://doi.org/10.1007/s10346-012-0349-1, 2013.

Günther, A., Eeckhaut, M. V. D., Malet, J.-P., Reichenbach, P., and Hervás, J.: Climate-physiographically differentiated Pan-European landslide susceptibility assessment using spatial multi-criteria evaluation and transnational landslide information, Geomorphology, 224, 69-85, https://doi.org/10.1016/j.geomorph.2014.07.011, 2014.

Guzzetti, F., Peruccacci, S., Rossi, M., and Stark, C. P.: Rainfall thresholds for the initiation of landslides in central and southern Europe, Meteor. Atmos. Phys., 98, 239-267, https://doi.org/10.1007/s00703-007-0262-7, 2007. 
Guzzetti, F., Peruccacci, S., Rossi, M., and Stark, C. P.: The rainfall intensity-duration control of shallow landslides and debris flows: an update, Landslides, 5, 3-17, https://doi.org/10.1007/s10346007-0112-1, 2008.

Hervás, J., Günther, A., Reichenbach, P., Chacón, J., Pasuto, A., Malet, J.-P., Trigila, A., Hobbs, P., Maquaire, O., Tagliavini, F., Poyiadji, E., Guerrieri, L., and Montanarella, L.: Recommendations on a common approach for mapping areas at risk of landslides in Europe, in: Guidelines for Mapping Areas at Risk of Landslides in Europe. Proceedings Experts Meeting, Ispra, Italy, 23-24 October 2007. JRC Report EUR 23093 EN, edited by Hervás, J., Office for Official Publications of the European Communities, Luxembourg, 2007.

Horn, B. K. P.: Hill shading and the reflectance map, Proceedings of the IEEE, 69, 14-47, https://doi.org/10.1109/PROC.1981.11918, 1981.

Imbery, F., Plagemann, S., and Namyslo, J.: Processing and analysing an ensemble of climate projections for the joint research project KLIWAS, Adv. Sci. Res., 10, 91-98, https://doi.org/10.5194/asr-10-91-2013, 2013.

IPCC: Climate Change: The IPCC Scientific Assessment (1990), Cambridge University Press, 1990.

IPCC: IPCC Second Assessment - Climate Change 1995, Cambridge University Press, 1995.

IPCC: IPCC Special Report on Emission Scenarios: A Special Report of IPCC Working Group III, Cambridge University Press, 2000.

IPCC: Climate Change 2001: Synthesis Report, A Contribution of Working Groups I, II, and III to the Third Assessment Report of the Integovernmental Panel on Climate Change, Cambridge University Press, 2001.

IPCC: Climate Change 2007: Synthesis Report, Contribution of Working Groups I, II and III to the Fourth Assessment Report of the Intergovernmental Panel on Climate Change, 2007.

IPCC: Managing the Risks of Extreme Events and Disasters to Advance Climate Change Adaptation, Cambridge University Press, 2012.

IPCC: Climate Change 2013: The Physical Science Basis: Working Group I Contribution to the Fifth Assessment Report of the Intergovernmental Panel on Climate Change, Cambridge University Press, https://doi.org/10.1017/CBO9781107415324, 2014a.

IPCC: Climate Change 2014: Synthesis Report, Contribution of Working Groups I, II and III to the Fifth Assessment Report of the Intergovernmental Panel on Climate Change, 2014b.

Jaedicke, C., Van Den Eeckhaut, M., Nadim, F., Hervás, J., Kalsnes, B., Vangelsten, B. V., Smith, J. T., Tofani, V., Ciurean, R., Winter, M. G., Sverdrup-Thygeson, K., Syre, E., and Smebye, H.: Identification of landslide hazard and risk "hotspots" in Europe, Bull. Eng. Geol. Environ., 73, 325-339, https://doi.org/10.1007/s10064-013-0541-0, 2014.

Keiler, M., Knight, J., and Harrison, S.: Climate change and geomorphological hazards in the eastern European Alps, Philos. T. R. Soc. Lond., 368, 2461-2479, https://doi.org/10.1098/rsta.2010.0047, 2010.

Kellermann, P., Schöbel, A., Kundela, G., and Thieken, A. H.: Estimating flood damage to railway infrastructure - the case study of the March River flood in 2006 at the Austrian Northern Railway, Nat. Hazards Earth Syst. Sci., 15, 2485-2496, https://doi.org/10.5194/nhess-15-2485-2015, 2015.
Koetse, M. J. and Rietveld, P.: The impact of climate change and weather on transport: An overview of empirical findings, Transport. Res. D.-Tr. E., 14, 205-221, https://doi.org/10.1016/j.trd.2008.12.004, 2009.

Loveridge, F., Spink, T., O'Brien, T., Briggs, K., and Butcher, D.: The impact of climate and climate change on infrastructure slopes with particular reference to southern England, Q. J. Eng. Geol. Hydroge., 43, 461-472, 2010.

Matulla, C., Groll, N., Kromp-Kolb, H., Scheifinger, H., Lexer, M., and Widmann, M.: Climate change scenarios at Austrian National Forest Inventory sites, Clim. Res., 22, 161-173, https://doi.org/10.3354/cr022161, 2002.

Matulla, C., Scheifinger, H., Menzel, A., and Koch, E.: Exploring two methods for statistical downscaling of Central European phenological time series, Int. J. Biometeorol., 48, 56-64, https://doi.org/10.1007/s00484-003-0186-y, 2003.

Matulla, C., Hollósi, B., Andre, K., Gringinger, J., Chimani, B., Namyslo, J., Fuchs, T., Auerbach, M., Herrmann, C., Sladek, B., Berghold, H., Gschier, R., and Eichinger-Vill, E.: Climate Change driven evolution of hazards to Europe's transport infrastructure throughout the twenty-first century, Theor. Appl. Climatol., https://doi.org/10.1007/s00704-017-2127-4, 2017.

McBean, G. A.: Coping with Global Environmental Change: Need for an Interdisciplinary and Integrated Approach, in: Coping with Global Environmental Change, Disasters and Security: Threats, Challenges, Vulnerabilities and Risks, edited by: Brauch, H. G., Oswald Spring, Ú., Mesjasz, C., Grin, J., Kameri-Mbote, P., Chourou, B., Dunay, P., and Birkmann, J., 1193-1204, Springer Berlin Heidelberg, Berlin, Heidelberg, https://doi.org/10.1007/978-3-642-17776-7_73, 2011.

Meyer, V., Becker, N., Markantonis, V., Schwarze, R., van den Bergh, J. C. J. M., Bouwer, L. M., Bubeck, P., Ciavola, P., Genovese, E., Green, C., Hallegatte, S., Kreibich, H., Lequeux, Q., Logar, I., Papyrakis, E., Pfurtscheller, C., Poussin, J., Przyluski, V., Thieken, A. H., and Viavattene, C.: Review article: Assessing the costs of natural hazards - state of the art and knowledge gaps, Nat. Hazards Earth Syst. Sci., 13, 1351-1373, https://doi.org/10.5194/nhess-13-1351-2013, 2013.

Natural Earth: Vector Data Set, v3.0.0.0, https://github.com/ nvkelso/natural-earth-vector, last access: 21 August 2017, 2017.

Nestroy, O.: Soil sealing in Austria and its consequences, Ecohydrology \& Hydrobiology, 6, 171-173, https://doi.org/10.1016/S1642-3593(06)70139-2, 2006.

Neuhäuser, B. and Terhorst, B.: Landslide susceptibility assessment using "weights-of-evidence" applied to a study area at the Jurassic escarpment (SW-Germany), Geomorphology, 86, 12 24, https://doi.org/10.1016/j.geomorph.2006.08.002, 2007.

OpenStreetMap contributors: Planet dump retrieved from https: //planet.osm.org, https://www.openstreetmap.org, last access: 29 March 2018.

OSM: Highway tag usage, https://wiki.openstreetmap.org/wiki/ Key:highway, last access: 21 August 2017, 2017.

Panagos, P.: The European soil database, GEO: connexion, 5, 3233, 2006.

Panagos, P., Liedekerke, M. V., Jones, A., and Montanarella, L.: European Soil Data Centre: Response to European policy support and public data requirements, Land Use Policy, 29, 329-338, https://doi.org/10.1016/j.landusepol.2011.07.003, 2012. 
Panagos, P., Ballabio, C., Borrelli, P., Meusburger, K., Klik, A., Rousseva, S., Tadić, M. P., Michaelides, S., Hrabalíková, M., Olsen, P., Aalto, J., Lakatos, M., Rymszewicz, A., Dumitrescu, A., Beguería, S., and Alewell, C.: Rainfall erosivity in Europe, Sci. Tot. Environ., 511, 801-814, https://doi.org/10.1016/j.scitotenv.2015.01.008, 2015.

Papathoma-Köhle, M. and Glade, T.: The role of vegetation cover change for landslide hazard and risk, in: The Role of Ecosystems in Disaster Risk Reduction, edited by: Renaud, G., SudmeierRieux, K., and Estrella, M., 293-320, UNU-Press, 2013.

Persichillo, M. G., Bordoni, M., Meisina, C., Bartelletti, C., Giannecchini, R., Avanzi, G. D., Galanti, Y., Cevasco, A., Brandolini, P., Galve, J. P., and Barsanti, M.: Slope Angle as Indicator Parameter of Landslide Susceptibility in a Geologically Complex Area, in: Landslides and Engineered Slopes. Experience, Theory and Practice. Proceedings of the 12th International Symposium on Landslides (Napoli, Italy, 12-19 June 2016), edited by: Aversa, S., Cascini, L., Picarelli, L., and Scavia, C., 1605-1612, CRC Press, Berlin, Heidelberg, https://doi.org/10.1201/b21520199, 2016.

Persichillo, M. G., Bordoni, M., and Meisina, C.: The role of land use changes in the distribution of shallow landslides, Sci. Tot. Environ., 574, 924-937, https://doi.org/10.1016/j.scitotenv.2016.09.125, 2017.

Peruccacci, S., Brunetti, M. T., Gariano, S. L., Melillo, M., Rossi, M., and Guzzetti, F.: Rainfall thresholds for possible landslide occurrence in Italy, Geomorphology, 290, 39-57, https://doi.org/10.1016/j.geomorph.2017.03.031, 2017.

Petitta, M., Pregnolato, M., Pedoth, L., and Schneiderbauer, S.: Relationship between landslide processes and land use-land cover changes in mountain regions: footprint identification approach., Geophys. Res. Abst., 17, 6927, 2015.

Pfurtscheller, C.: Regional economic impacts of natural hazards - the case of the 2005 Alpine flood event in Tyrol (Austria), Nat. Hazards Earth Syst. Sci., 14, 359-378, https://doi.org/10.5194/nhess-14-359-2014, 2014.

Pfurtscheller, C. and Thieken, A. H.: The price of safety: costs for mitigating and coping with Alpine hazards, Nat. Hazards Earth Syst. Sci., 13, 2619-2637, https://doi.org/10.5194/nhess13-2619-2013, 2013.

Pfurtscheller, C. and Vetter, M.: Assessing entrepreneurial and regional-economic flood impacts on a globalized production facility, J. Flood Risk Manage., 8, 329-342, https://doi.org/10.1111/jfr3.12102, 2015.
Postance, B., Hillier, J., Dijkstra, T., and Dixon, N.: Extending natural hazard impacts: an assessment of landslide disruptions on a national road transportation network, Environ. Res. Lett., 12, 014010, https://doi.org/10.1088/1748-9326/aa5555, 2017.

Promper, C., Puissant, A., Malet, J.-P., and Glade, T.: Analysis of land cover changes in the past and the future as contribution to landslide risk scenarios, Appl. Geogr., 53, 11-19, https://doi.org/10.1016/j.apgeog.2014.05.020, 2014.

Reichenbach, P., Busca, C., Mondini, A. C., and Rossi, M.: The Influence of Land Use Change on Landslide Susceptibility Zonation: The Briga Catchment Test Site (Messina, Italy), Environ. Manage., 54, 1372-1384, https://doi.org/10.1007/s00267-0140357-0, 2014.

Schlögl, M. and Laaha, G.: Extreme weather exposure identification for road networks - a comparative assessment of statistical methods, Nat. Hazards Earth Syst. Sci., 17, 515-531, https://doi.org/10.5194/nhess-17-515-2017, 2017.

Sidle, R. C. and Ochiai, H.: Landslides: Processes, Prediction, and Land Use, American Geophysical Union, https://doi.org/10.1029/WM018, 2013.

Terhorst, B.: Periglacial cover beds and soils in landslide areas of SW-Germany, CATENA, Catena, 71, 467-476, 2007.

Van Den Eeckhaut, M., Hervás, J., Jaedicke, C., Malet, J.-P., Montanarella, L., and Nadim, F.: Statistical modelling of Europewide landslide susceptibility using limited landslide inventory data, Landslides, 9, 357-369, https://doi.org/10.1007/s10346011-0299-z, 2012.

von Storch, H., Zorita, E., and Cubasch, U.: Downscaling of Global Climate Change Estimates to Regional Scales: An Application to Iberian Rainfall in Wintertime, J. Climate, 6, 1161-1171, https://doi.org/10.1175/15200442(1993)006<1161:DOGCCE>2.0.CO;2, 1993.

Wilson, M. F. J., O'Connell, B., Brown, C., Guinan, J. C., and Grehan, A. J.: Multiscale Terrain Analysis of Multibeam Bathymetry Data for Habitat Mapping on the Continental Slope, Marine Geodesy, 30, 3-35, https://doi.org/10.1080/01490410701295962, 2007. 